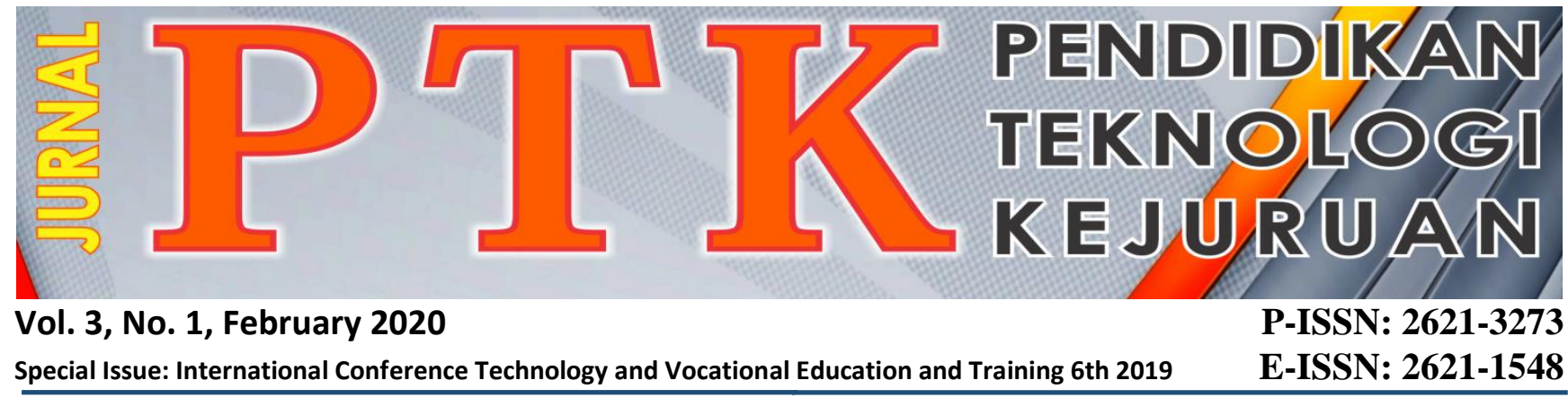

\title{
TEACHING MATERIAL DEVELOPMENT ORIENTED ON THE SAINTIFIC APPROACH OF 5M IN LEARNING AUTOMOTIVE BASIC TECHNOLOGY
}

\author{
Supriadi, Suparno, Giatman, and Edidas \\ ${ }^{1}$ SMK Negeri 1 Padang \\ ${ }^{2}$ Universitas Negeri Padang \\ *Corresponding author, e-mail: supriadi.fkip@gmail.com
}

\begin{abstract}
The purpose of this research is to develop interactive learning media on computer and basic networks subject that are valid, practical and effective. This reasearch is used the Four-D design model that is applied to develop and test the validity, practicality and effectiveness of interactive learning media in computer and basic networking learning. The research is used the Four-D model include defining, designing, developing, and distributing. The results of the validity test on interactive learning media are valid. Based on teachers and students responses about instructional media shows the results of interactive learning media are very practical and learning outcomes from students indicate the learning media has been effectively used for computer and basic networking learning. The analysis resultshows that interactive learning media is better in improving student learning processes
\end{abstract}

Keywords: Interactive Learning Media, Four-D, Computer and Basic Networking

Copyright $\odot 2020$ JPTK. All rights reserved

\section{INTRODUCTION}

Considering the demands of education in the 21 st century, the government designed an effort by evaluating and developing curriculum to improve the quality of education in Indonesia. Curriculum development carried out by the government at this time is the development of the 2013 curriculum. The 2013 curriculum development is the development of the two previous curricula. First, Competency Based Curriculum (CBC). Second, Education Unit Level Curriculum (KTSP). In this case, the 2013 curriculum development is focused on the formation of competencies and character of students, in the form of a combination of knowledge, skills, and attitudes that students can demonstrate as a form of understanding of the concepts learned by students.

Vocational high school (SMK) aims to create a skilled and competent manpower. This is in accordance with the national education goals described in Law Number 20 Year 2003, which is to develop the potential of students to become knowledgeable, capable, creative, and independent human beings, and then to become democratic citizens with responsibilities [1]. It was clarified in Regulation of the Minister of National Education No. 23/2006 that the Competency Standards for
Vocational Education Graduates were to master the competency of the expertise and entrepreneurship program both to meet the demands of the workforce and to attend high education in accordance with the Regulation of the Education for Vocational Training [2].

Teaching materials are needed to support student competence. Teaching Materials are all materials (information, tools, and texts) that are arranged systematically, which displays the full features of competencies that will be mastered by students [3]. Good teaching materials do not only contain material that is in accordance with the curriculum, but must be written with a high level of readability [4]. In the book "Guidelines for Development of Teaching Materials" Depdiknas. Teaching material serves as a guideline for teachers who will direct all their activities in the learning process, at the same time it is a substance of competence that should be taught to students, a guideline for students that will direct all of their activities in the learning process, as well as a substance of competencies that should be mastered, which is an evaluation tool for achievement or mastery of learning outcomes [5]. the competencies that must be achieved by students are elaborated in Core Competencies (KI) consisting 
of four competencies, namely core competencies regarding spiritual attitudes (KI 1), core competencies concerning social attitudes (KI 2), core competencies concerning knowledge (KI 3), and competencies core on skills (KI 4) [6]. The contents of the teaching material section presents an introductory part consisting of core competencies and basic competencies, module descriptions, time, prerequisites, instructions for using the module, final objectives, mastery checks, concept maps, the learning section consists of material description, a 5M scientific approach, illustrative drawings that are according to real life, features in teaching materials, summaries, and in the evaluation section there is an attitude assessment for students, an evaluation that contains questions, feedback, and there are also remedies and enrichments according to the Minister of Education and Culture Regulations 104 states that for students who have not successfully achieved the criteria given the opportunity to participate in remedies and for students who have succeeded can be given an enrichment program which is a deepening of the competencies learned. The closing section presents a glossary, bibliography, answer key and back cover [7]. Teaching materials are arranged systematically and used to help teachers in the learning process so that learning is effective and efficient. Teaching materials have a great influence on students' success in the learning process. Teaching material as a learning tool that contains learning materials, methods and ways to evaluate that are designed in a systematic and interesting way.

The first real condition was obtained from the results of Indonesian students' understanding of the 2015 PISA assessment announced at the beginning of December 2016 which showed that Indonesia ranked 64th out of 72 countries with a score of 397 (average score of OECD 493). During 2012-2015, the PISA score only rose by 1 point from 396 to 397 for reading ability. So it can be concluded that the understanding of Indonesian students is still very low which is not in line with expectations [8]. The second real condition is obtained from the observation of teacher teaching materials in vocational high school 1-Padang. The results show that teaching materials are not yet available and the application of learning oriented to the scientific approach of $5 \mathrm{M}$ has been applied but not yet maximized.

The teaching materials used have not been able to support independent learning, so students only rely on the learning process in class. When students rely solely on the learning process in class, it has an impact on the number of failures in the implementation of learning. As an example of the results of the evaluation of the Final Examination Semester in Academic Year 2018/2019 described in table 1.

Table 1. Evaluation Results for Semester Final Examination in Academic Year 2018/2019

\begin{tabular}{|l|l|c|c|}
\hline \multicolumn{3}{|c|}{ Basic competencies } & \multicolumn{2}{|c|}{ Total students } \\
\cline { 3 - 4 } & Succeed & $\begin{array}{l}\text { Un- } \\
\text { succeed }\end{array}$ \\
\hline $\begin{array}{l}\text { Understanding the } \\
\text { energy conversion } \\
\text { engine process }\end{array}$ & $\begin{array}{l}\text { Demonstrating } \\
\text { energy } \\
\text { conversion } \\
\text { machines }\end{array}$ & 20 & 12 \\
\hline $\begin{array}{l}\text { Understanding } \\
\text { engine } \\
\text { classification }\end{array}$ & $\begin{array}{l}\text { Identifying } \\
\text { engine models }\end{array}$ & 18 & 14 \\
\hline $\begin{array}{l}\text { Understanding } \\
\text { how the engine } \\
\text { works 2 and 4 } \\
\text { steps }\end{array}$ & $\begin{array}{l}\text { Explaining how } \\
\text { the engine } \\
\text { works 2 and 4 } \\
\text { steps }\end{array}$ & 23 & 9 \\
\hline
\end{tabular}

Data source from teachers of Automotive Basic Technology subjects.

Table 1 explains that the average success rate of each KD in class X semester January - June 2019 is only around $60.92 \%$. The problem is still an average of $39.08 \%$ of students who fail. Students who fail are required to repeat the lesson. The main objective of the development of this teaching material is to increase students' understanding of the subject matter which has an impact on decreasing failure rates and improving student learning outcomes. Development of teaching materials is able to minimize these problems by using the Discovery Learning model through a scientific approach.

Automotive basic technology teaching materials oriented scientific approach of $5 \mathrm{M}$ has several advantages. First the material presented in teaching material starts from the PISA context, which is linking the material with the real world so that students more easily understand the material. Second, learning develops students' thinking skills according to the problems they face. Third, it can increase students' interest in reading about basic automotive technology materials. Fourth, the use of teaching materials can improve student competency.

Based on the problems that occur, we need an innovative, creative, and appropriate teaching material in accordance with the 2013 curriculum so that it can attract the attention of students to actively learn basic automotive technology materials. One alternative is to develop supporting teaching 
materials oriented to the scientific approach of $5 \mathrm{M}$. The problems formulated in this study are 1) How to develop teaching materials oriented towards the scientific approach of $5 \mathrm{M}$ in automotive basic technology subjects at Vocational High School 1Padang 2) How is the validity of teaching materials oriented in the scientific approach of $5 \mathrm{M}$ in automotive basic technology subjects at Vocational High School 1-Padang 3) How is the practicality of teaching materials oriented in a scientific approach to the basic automotive technology subjects at Vocational High School 1- Padang.

Based on the formulation of the problem, the objectives in this study are 1) Producing teaching materials oriented to the scientific approach of $5 \mathrm{M}$ in automotive basic technology subjects at Vocational High School 1- Padang 2) Knowing the validity of teaching materials oriented towards the scientific approach of 5M in subjects basic automotive technology at Vocational High School 1Padang. 3) Knowing the practicality of teaching materials oriented scientific approach of $5 \mathrm{M}$ in automotive basic technology subjects at Vocational High School 1- Padang.

\section{METHODOLOGY}

This type of research is a research development that aims to produce teaching materials oriented to the scientific approach of $5 \mathrm{M}$ automotive basic technology subjects at Vocational High School 1Padang which is valid and practical but the teaching material is said to be valid if it reflects knowledge. Said to be practical if people who use the product assume that the product can be used (usable) for the learning process.

The subjects in this study were students' expertise programs of automotive engineering in class $X$ of vocational high school 1-Padang. The object of this research is the development of teaching materials oriented to the scientific approach of $5 \mathrm{M}$ in automotive basic technology subjects in vocational high school 1-Padang.

As a foundation for the development of teaching materials oriented towards the scientific approach of $5 \mathrm{M}$ in automotive basic technology subjects in vocational high school 1-Padang, researchers used the Rowntree development model (Prawiradilaga, 2008). The development procedure consists of three stages namely, the planning stage, the development stage, and the evaluation stage.

Evaluation activities are carried out in stages as stated by Warsita (2008: 240) following stages of evaluation activities, according to Tessmer: (a) expert evaluation, (b) one-to-one evaluation, (c) small group evaluation and (d) field test. [9]

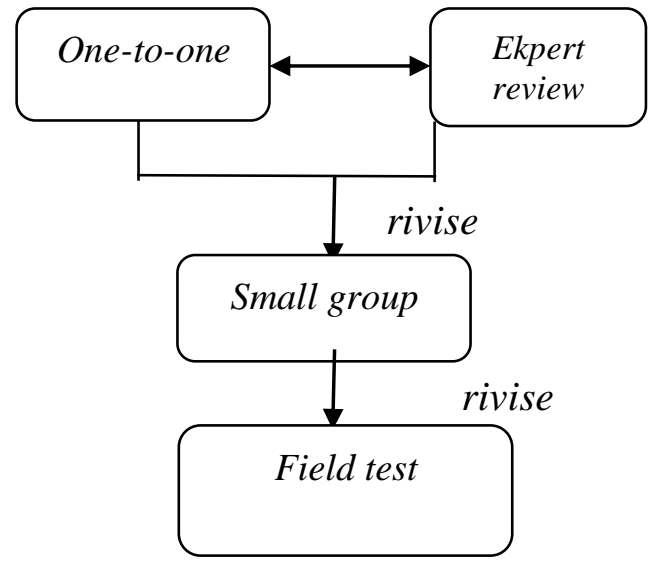

Figure 1. Chart of evaluation activities according to Tessmer.

Data analysis is an activity after data from all respondents or other data sources have been collected [10]. Validity analysis uses a Likert scale based on the validation sheet with the Scoring steps for each indicator with a scale of 1-5 as follows: Value 1 = invalid; Value 2 = less valid; Value $3=$ valid enough; Value 4 = valid; Value $5=$ very valid. [10]

Practicality data is obtained from data provided by teachers and students. To analyze the user response sheet teaching materials used descriptive analysis by giving a value to the aspects observed with a scale of Value $1=$ Disagree; Value $2=$ Disagree; Value 3 = Quite agree; Value 4=Agree; Value $5=$ Strongly agree

No Level of achievement (\%) Category.

Table 2. Level of achievement

\begin{tabular}{|c|c|c|}
\hline No & $\begin{array}{c}\text { Level of achievement } \\
(\mathbf{\%})\end{array}$ & Category \\
\hline 1 & $85-100$ & Very practical \\
\hline 2 & $75-84$ & practical \\
\hline 3 & $60-74$ & Enough practical \\
\hline 4 & $55-59$ & Less practical \\
\hline 5 & $0-54$ & Not practical \\
\hline
\end{tabular}

Based on these criteria, the teaching material of the teaching material in this study is said to be eligible if the achievement level is $75 \%-100 \%$.

\section{RESULT AND DISCUSSION}

This development uses the Rowntree development model, but this development only reaches the development stage, because the fourth stage is not carried out due to time and cost limitations. 
The design phase is carried out to design automotive basic technology teaching materials based on the scientific approach of $5 \mathrm{M}$ on automotive basic technology materials. This design phase includes two steps, namely the selection of the format and design of teaching materials, the format of teaching materials starts from the front cover of teaching materials to the back cover of teaching material. Designing teaching materials is an activity to design teaching models or physical teaching materials to make them more interesting and motivate students to learn. The development phase aims to produce automotive basic technology teaching materials based on a scientific approach of $5 \mathrm{M}$ that is eligible. The eligibility of this teaching material is measured through a study of suggestions or input and validation by expert namely material experts, linguists and graphic experts. The effectiveness of teaching materials is measured through the results of student responses after reading teaching materials obtained from filling out a questionnaire through limited trials.

The study of teaching materials is carried out to obtain input for the improvement of teaching materials that are developed. Improvements made to the teaching materials of the scientific approach of $5 \mathrm{M}$ based on input from material experts include: 1) core competencies 1 and 2 are equipped with illustrations of negative or positive event occurrences, 2) add practice exercises to the evaluation section. Improvements made to the teaching material of the scientific approach of $5 \mathrm{M}$ based on input from linguists, among others: 1) adjusting between one part with another, 2) replacing your (in singular) into you (in plural), 3) changing words bibliography becomes a reference list. Improvements made to teaching materials based on a scientific approach of $5 \mathrm{M}$ based on input from graphic experts include: 1) using the same color on the front and back covers, 2) reducing the use of too many colors, 3) changing the illustration images to be clearer.

The reliability of teaching materials based on the scientific approach of $5 \mathrm{M}$ on the developed automotive basic technology material can be known from the results of the validation of the experts. The validation results can be in the form of a rating scale from each validator. Expert validation was obtained from a closed questionnaire to assess the draft of the teaching material developed.

The results of the validation are quantitative data that is used as a basis for determining the eligibility of teaching materials in the following table:
Table 3. A basis for determining the eligibility of teaching materials

\begin{tabular}{|c|l|c|c|}
\hline No & Eligibility component & $\mathbf{( \% )}$ & Criteria \\
\hline 1 & Content eligibility & 77,5 & Eligible \\
\hline 2 & $\begin{array}{l}\text { Eligibility of } \\
\text { presentation }\end{array}$ & $82 \%$ & $\begin{array}{c}\text { Very } \\
\text { Eligible }\end{array}$ \\
\hline 3 & Eligibility of languages & 86,2 & $\begin{array}{c}\text { Very } \\
\text { Eligible }\end{array}$ \\
\hline 4 & Eligibility of graphics & 83,15 & $\begin{array}{c}\text { Very } \\
\text { Eligible }\end{array}$ \\
\hline \multicolumn{2}{|l|}{ Overall average } & 82,2 & $\begin{array}{c}\text { Very } \\
\text { Eligible }\end{array}$ \\
\hline
\end{tabular}

The results of the average assessment of the validation of teaching material products as shown in Table 2 are presented in the following graph:

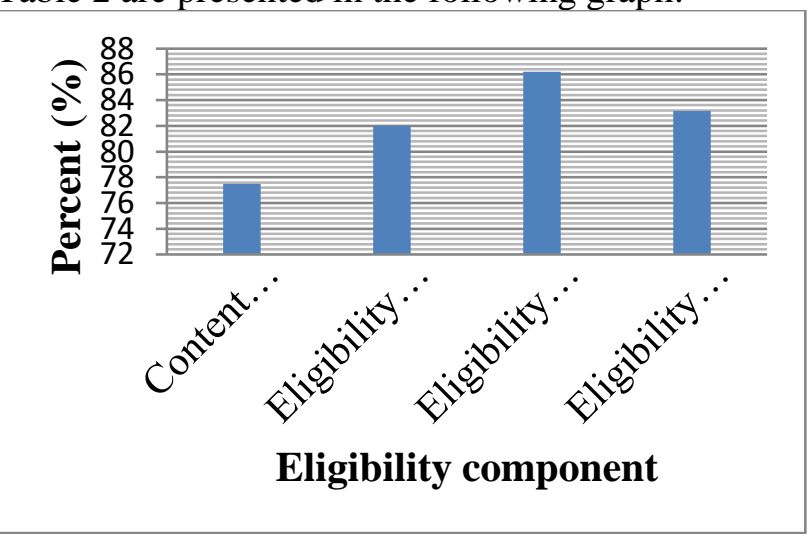

Figure 2. Graphic validation of teaching material products

Based on the average table of the overall percentage of content eligibility, presentation, language, and graphic categorized as "Very Eligible"

Trial is limited to aiming at knowing students' responses to modules that have been developed. The method of data collection is done by asking students to fill in the student response questionnaire; the student response questionnaire contains two criteria including the content of the material and the presentation. Table 3. Analysis of anget response of limited trial students.

Table 4. Data on the results of the quality assessment criteria of students

\begin{tabular}{|l|c|c|c|c|c|}
\hline Aspect & $\begin{array}{c}\text { Averag } \\
\text { e } \\
\text { Range of } \\
\text { Scores }\end{array}$ & $\begin{array}{c}\text { Range of } \\
\text { Scores }\end{array}$ & $\begin{array}{c}\text { Max } \\
\text { Score }\end{array}$ & $\begin{array}{c}\text { Descriptio } \\
\mathbf{n}\end{array}$ & $\begin{array}{c}\text { Percent } \\
(\%)\end{array}$ \\
\hline $\begin{array}{l}\text { Presentation } \\
\text { of material }\end{array}$ & 26 & $\begin{array}{c}23<\mathrm{x} \leq \\
28\end{array}$ & 28 & $\begin{array}{c}\text { Very } \\
\text { Good }\end{array}$ & 92,38 \\
\hline $\begin{array}{l}\text { Langaug } \\
\text { e }\end{array}$ & 15 & $13<\mathrm{x} \leq 16$ & 16 & $\begin{array}{c}\text { Very } \\
\text { Good }\end{array}$ & 93,96 \\
\hline $\begin{array}{l}\text { Graphica } \\
\text { l }\end{array}$ & 26 & $23<\mathrm{x} \leq 28$ & 28 & $\begin{array}{c}\text { Very } \\
\text { Good }\end{array}$ & 93,93 \\
\hline Benefits & 15 & $13<\mathrm{x} \leq 16$ & 16 & $\begin{array}{c}\text { Very } \\
\text { Good }\end{array}$ & 93,54 \\
\hline Average & \multicolumn{5}{|c|}{$93,45 \%$ (Very Good) } \\
\hline
\end{tabular}


Table 5. Acquisition of student quality assessment scores

\begin{tabular}{|c|c|c|c|c|c|}
\hline \multirow{2}{*}{$\begin{array}{c}\text { Assessment } \\
\text { Aspects }\end{array}$} & \multicolumn{4}{|c|}{ \% Score } & \multirow{2}{*}{$\begin{array}{c}\text { Number of items } \\
\text { rated }\end{array}$} \\
\hline & 4 & 3 & 2 & 1 & \\
\hline $\begin{array}{l}\text { Presentation } \\
\text { of material }\end{array}$ & 73 & 32 & 0 & 0 & 28 \\
\hline Language & 76 & 24 & 0 & 0 & 16 \\
\hline Graphical & 76 & 24 & 0 & 0 & 28 \\
\hline Benefits & 74 & 26 & 0 & 0 & 16 \\
\hline
\end{tabular}

The results of the average assessment of students on teaching material products such as those in Table 4 are presented in the following graph:

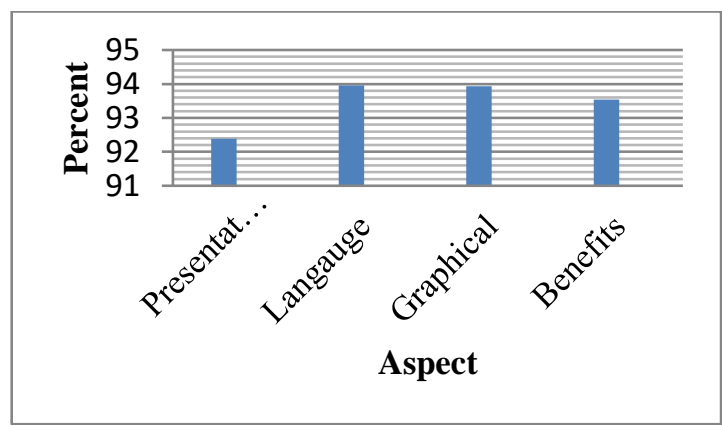

Figure 3. Graphic quality score assessment on the display aspect

Based on the student response questionnaire, students' opinions regarding the presentation of teaching materials obtained very good criteria is the percentage of 92.38, the language component obtained very good criteria is the percentage of $90.85 \%$, the graphic component is the percentage of 93.93\% and the benefits component is by percentage of $93.54 \%$ The average overall limited trial is obtained percentage of $93.45 \%$ categorized as "Very Good".

\section{CONCLUSIONS}

Based on the results of research and development $(\mathrm{R} \& \mathrm{D})$ and discussion, it can be concluded that the development of Automotive Basic Technology teaching materials for vocational students is very feasible to be used as teaching materials in class $\mathrm{X}$ using a scientific approach, so that the conclusion of the assessment results from experts that the teaching materials reached an average yield of $82.22 \%$ with the criteria "very feasible. After the product is validated, it will then be tested. The response of students on the appropriateness and attractiveness of the teaching materials of Basic Automotive Technology produced is proven to be feasible to use and interesting for students. In the trial questionnaire from the response of students who were tested reached an average of $93.45 \%$, so that the percentage can be said that the product is included in the criteria "very practical". Thus, the development of
Automotive Basic Technology teaching materials for vocational students is feasible and practical for students.

\section{REFERENCE}

[1] Aninomous. Republic of Indonesia Law No. 20, 2003, concerning the National Education system. 2003.

[2] Minister of national education regulation. Education Unit Level Curriculum. Jakarta: Directorate of Vocational High School Development and Learning Sub-Directorate. . 2006.

[3] Prastowo, A. Creative Guide to Making Innovative Teaching Materials. Yogyakarta: Diva Press. 2011.

[4] Jatnika, A. W. Level of Readability of Science Discourse with Klos Technique. Journal of Sociotechnology, 6(10), 196-200. Retrieved from

http://journals.itb.ac.id/index.php/sostek/articl e/view/972. 2014.

[5] Department of national education. Guidelines for Development of Teaching Materials. Jakarta: Department of national education. 2008.

[6] Ministry of Education and Culture. A curriculum development. Jakarta: Ministry of Education and Culture. 2013.

[7] Number, P. 104 in Assessment of Learning Outcomes by Educators in Primary and Secondary Education. 2014.

[8] Ibda, H. Strengthening of New Literacy in Madrasah Ibtidaiyah Teachers in Answering the Challenges of the Industrial Revolution Era 4.0. JRTIE: Journal of Research and Thought of Islamic Education, 1(1), 1-21. 2018.

[9] Warsita, Bambang. Learning Technology, Its Platform and Applications. Rineka Cipta, Jakarta. 2008.

[10] Sugiyono. Quantitative, Qualitative Research Methods, and R\&D. Bandung: Alphabet. 2011.

[11] S. Syahril, N. Jalinus, R. A. Nabawi, and Y. Arbi, "The Create Skills of Vocational Students to Design a Product: Comparison Project Based Learning Versus Cooperative Learning-Project Based Learning," Adv. Soc. Sci. Educ. Humanit. Res., vol. 299, no. 5th UPI International Conference on Technical and Vocational Education and Training (ICTVET 2018) The, pp. 316-320, 2019. 